\title{
The Vulnerability Assessment Method for Beijing Agricultural Drought
}

\author{
Lingmiao Huang, Peiling Yang, and Shumei Ren \\ College of Water Resources \& Civil Engineering, China Agricultural University, \\ Beijing 100083, China \\ huanglingmiao@cau.edu.cn, \{yangpeiling, renshumei\}@126.com
}

\begin{abstract}
Drought is a major disaster which Beijing agricultural systems faced with, build drought warning mechanism we need in-depth analysis the causes and mechanism of the drought to provide a basis for scientific disaster reduction and prevention. VAM vulnerability assessment method, selected 15 factors represent drought exposure, sensitivity and adaptive capacity, based on improved analytic hierarchy process to determine the weight of each factors, use K-means clustering algorithm to generate the drought vulnerability index system of research district. Draw vulnerability zoning map based on ArcGIS.
\end{abstract}

Keywords: Vulnerability, Assessment, Index System, VAM, Agricultural Drought.

\section{$1 \quad$ Introduction}

The risk of natural disasters is a result of natural disasters together with vulnerability, the level of loss risk is directly related with social vulnerability, to a great extent, decided by the vulnerability of hazard bearing [1]. Agricultural drought vulnerability means the property and status of agricultural production which is sensitive to drought and easily threatens by drought, as well as caused loss [2]. The impact factors of drought vulnerability are multifaceted [3].

Several scholars study on drought vulnerability in recent years, they focus on establishing drought vulnerability system based on a set of indicators. Liu Lanfang et al. [4] select nine indicators: precipitation, evaporation, the level of irrigation works and so on to evaluate vulnerability of agricultural drought in Hunan province. Wang Xiaohong et al.[5] develop a risk assessment model for agricultural drought, which includes the occurrence probability of drought, capacity of drought prevention, percentage of planting area, etc. Ni Shenghai et al. [6] select seven indicators to evaluate the Chinese agricultural drought vulnerability, according to the three elements, water resources characteristics, agriculture suffering drought and forming drought disaster circumstance and drought relief ability of water conservancies' facilities of the every locality, Wang Jingai et al.[7] obtains the distributional laws between the agricultural hazard- affected bodies and the centers of drought disaster in China based on regional combination of the hazard - formation factors with hazard affected bodies. select three counties as typical hazard - affected bodies, i. e. the 
rainfed field (Xinghe County), the irrigated field (Xingtai County) \& the paddy field (Dingcheng County), set up a vulnerability diagnosis index system of agricultural drought disaster and put forward a regional assessment model of agricultural drought vulnerability, including the frangibility-adaptability model of the rainfed field, the production - living pressure model of the irrigated field and the water demand supply model of the paddy field. Qiu Lin et al. [8] present threshold value of grade interval of estimation for vulnerability of agricultural drought in Hengyang city. According to variable fuzzy set theory, the variable fuzzy analysis method of multiple attribute and grades was proposed for quantitative estimation for vulnerability of agricultural drought disaster. Chen Ping, Chen Xiaoling, [9] select fourteen indicators representing exposure, sensitivity and adaptive capacity to droughts respectively. The weights of the indicators were calculated by analytic hierarchy process. Then using the composite index approach these indicators were combined into a drought vulnerability index of agricultural system by a linear aggregation. On the basis of the relationship between the drought vulnerability and exposure, sensitivity and adaptive capability, some suggestions for the drought hazard management in the future were proposed. Simelton et al. [10] identify socio-economic indicators associated with sensitivity and resilience to drought for each of China's main grain crops (rice, wheat and corn). Provincial harvest and rainfall data (1961-2001) are used to calculate an annual "crop-drought vulnerability index". Leads us to propose a series of droughtvulnerability typologies based on the extent to which land, labor, capital, agricultural technology, and infrastructure buffer or exacerbate the effect of a drought event.

We commonly used drought index to indicate the degree of drought [11], however, it needs combine with drought vulnerability to accurately reflect drought risk. Yi Zhengjie et al.[12] built a farm soil moisture balance model together with simulation of soil moisture during crop's growth stages. In this way soil moisture simulation and drought degree evaluation are united to conduct dynamic evaluation of agricultural drought, which provides a handy and feasible method of real-time dynamic evaluation of agricultural drought through soil moisture simulation. Many scholars also have taken study on drought assessment of winter wheat in northern China. Wang Suyan et al.[13] based on understanding influence of water on the productive potentialities of winter wheat in semihumid, semi-arid areas of northern China under natural climate condition, the "correction step by step" is used to calculate photosynthesis potential productivity, photo-temperature productivity and climate productive potentialities. Analysis the dynamic changes of winter wheat water and climate production potential in north China during the past 40 years. Sun Ning, Feng Liping et al.[14] Based on validation of two crop growth models (W heat SM and APSIM-W heat) for the winter wheat yield simulation of Beijing. Zhang Wenzong et al. [15] present a methodology for risk assessment and division of winter wheat drought hazard in Hebei Province, including the concept, calculation method and regional distribution of the disaster risk index. Also discussed the average decreasing rate, the disaster prevention and mitigation measures of dry year with different intensities and loses in different kind of risk areas.

During the growth period of winter wheat in northern winter wheat region, precipitation is mostly less than 250 millimeter. Along a gradient that sees increased aridity from south to north. In Beijing-Tianjin area, the precipitation has been less than 150 millimeter. But the water demand for the growth period was about 350 500 millimeter and the 
demand for critical period was 200 250 millimeter, lack of 300 millimeter water [16]. The growth period of winter wheat in Beijing start from late September to mid-June [17], the rainfall of Beijing area is generally concentrated in the June to August, appear the phenomenon of precipitation and growth period of winter wheat water requirement dislocation, drought is a direct threat to stable and high yield of winter wheat, even has a serious impact on the socio-economic. It is urgent to carry out the study on Beijing drought vulnerability and reduce drought disasters.

The aim of this paper is to develop and apply a quantitative approach to agricultural drought vulnerability assessment within Beijing to identify which of the country's regions and districts are most vulnerable to drought. To achieve this aim, the study objectives are:

a) To establish an index system for the assessment of agricultural drought based on the three elements of drought vulnerability;

b) To select 15 factors represent drought exposure, sensitivity and adaptive capacity, based on improved analytic hierarchy process to evaluate the exposure, adaptive capacity and sensitivity of Beijing's eleven regions and the districts within the most vulnerable regions;

\section{Materials and Methods}

\subsection{Study Area}

Beijing is located in the longitude of $115^{\circ} 20^{\prime}$ to $117^{\circ} 30^{\prime}$ and the latitude of $39^{\circ} 25^{\prime}$ to $41^{\circ}$. About $150 \mathrm{~km}$ distance to the west of Bohai, located in the northwest edge of the North China Plain, the city's total area is $16410.54 \mathrm{~km}^{2}$, mountain area account for $62 \%$, and about $38 \%$ of the areas are plains. Beijing is surrounded by the Taihang Mountains and Yanshan Mountains in its western and northern, its southeast is a plain. The terrain is higher in the west; north and northeast, while inclined to the south and southeast.

The populations of Beijing are about 20 million; multi-year average precipitation is $585 \mathrm{~mm}$, the city's total water resources are 2.308 billionm $^{3}$, however, water resources per capita are only $107 \mathrm{~m}^{3}$, water resources are very scarce. From the history of drought disasters in Beijing, Beijing's drought is divided into three categories: spring drought, the early summer drought, summer drought. In recent years, the drought frequent occurred in Beijing, except the lower droughts loss rate during the year 1990 to 1998 , since 1999, the drought loss rates were at high value. The impact of drought on agriculture was very big, evaluating and predicting spatial distribution of a given period of the potential risks of agricultural systems in Beijing which affected by the drought is particularly important to provide the basis for scientific disaster prevention and mitigation.

\subsection{Research Method}

In this paper, using VAM vulnerability assessment methods [18], the three elements of vulnerability classified as exposure, sensitivity, and adaptive capacity. Exposure 
represent that system experience a degree of drought stress, it is related to the intensity, frequency and duration of the drought; sensitivity is the extent of agricultural system elements susceptible to the effects of drought; adaptive capacity is the behavior that stakeholders in the agricultural system taking to reduce the effects of drought in the pre-disaster and after disaster. The results of exposure, sensitivity, and adaptive capacity Co-expressed as drought vulnerability.

Using the formula [1]

$$
\mathrm{V}=\mathrm{f}(\mathrm{E}, \mathrm{S}, \mathrm{A})
$$

By the composite indicator method, the vulnerability results can be expressed as various indicators and the linear plus of their corresponding weights:

$$
\mathrm{V}=\sum_{\mathrm{i}=1}^{\mathrm{n}} \mathrm{I}_{\mathrm{i}} \times \mathrm{w}_{\mathrm{i}}+\sum_{\mathrm{l}=1}^{\mathrm{m}} \mathrm{I}_{\mathrm{l}} \times \mathrm{w}_{\mathrm{l}}+\sum_{\mathrm{r}=1}^{\mathrm{s}} \mathrm{I}_{\mathrm{r}} \times \mathrm{w}_{\mathrm{r}}
$$

In the formula (1), $\mathrm{V}$ is drought vulnerability indicator of the evaluation unit; $\mathrm{E}$ is drought exposure indicator; $\mathrm{S}$ is drought sensitivity indicator; $\mathrm{A}$ is drought adaptability indicator. There are respectively multiplied by the evaluation indicator scores that belonging to the three elements and the corresponding weight of evaluation indicator. The $I_{i} 、 I_{l} 、 I_{r}$ are the score of evaluation indicator $i, 1, r ; W_{i} 、 W_{l} 、 W_{r}$ are the weight value of the evaluation indicator i、 $1, r$.

\subsubsection{Establishment of the Evaluation Indicator System}

Select representative sub-elements from the three elements: exposure, sensitivity and adaptive capacity in order to refine the three elements. this article focus on Beijing agricultural drought vulnerability, Beijing's high incidence of drought period was consistent with the growth of winter wheat, so the index system of this article mainly focus on considering the difference value between evaporation and rainfall in the winter wheat planting period and the proportion of winter wheat growth.

\begin{tabular}{|c|c|c|c|c|}
\hline Element & Evaluation indicators & $\begin{array}{l}\text { The explain of evaluation } \\
\text { indicators }\end{array}$ & Data sources & Time \\
\hline \multirow{3}{*}{ Exposure (E) } & $\begin{array}{l}\text { Difference value } \\
\text { between evaporation } \\
\text { and rainfall/mm }(+)\end{array}$ & $\begin{array}{l}\text { Reflects the degree of } \\
\text { crop water demand is } \\
\text { satisfied }\end{array}$ & $\begin{array}{l}\text { China } \\
\text { Meteorological } \\
\text { Data Sharing } \\
\text { Network }\end{array}$ & \multirow{3}{*}{2010} \\
\hline & $\begin{array}{l}\text { Average } \\
\text { elevation/m(+) }\end{array}$ & $\begin{array}{l}\text { Elevation is positively } \\
\text { related to water } \\
\text { abstraction difficulty } \\
\text { during the drought period }\end{array}$ & $\begin{array}{l}\text { International } \\
\text { Scientific }\end{array}$ & \\
\hline & $\begin{array}{l}\text { Average slope }{ }^{\circ} \\
(+)\end{array}$ & $\begin{array}{l}\text { The slope affect soil } \\
\text { water retention capacity, } \\
\text { increasing the severe } \\
\text { drought period irrigation } \\
\text { difficulty }\end{array}$ & $\begin{array}{l}\text { Database ( } 90 \\
\text { meter } \\
\text { resolution data) }\end{array}$ & \\
\hline
\end{tabular}

Table 1. List of drought vulnerability indicators 
Table 1. (Continued.)

The river network density/ $\left(\mathrm{km} / \mathrm{km}^{2}\right)$

(-)

\section{Forest coverage $1 \%$} $(-)$

Lack of precipitation, surface runoff is a major water sources of production and living

Influence the climate of the area and the conservation of rainfall

The proportion of The irrigation index effective irrigation area in (-) the total area of cultivated land

Winter wheat The proportion of planting ratio $(+)$ winter wheat acreage in the total cultivated area The agricultural population groups are most sensitive to drought

The proportion of facilities agricultural area in the total cultivated area

Indicator of the degree of cultivated land use

The lower, the more

Grain yield per unit area/ $\left(\mathrm{t} / \mathrm{hm}^{2}\right)(-)$ serious the impact of drought decrease yields, the more sensitive to drought

Reflect the level of the

Rural electricity rural economy, as well as consumption $/ 10^{4} \mathrm{kwh}(-$ the time and the frequency use of agricultural machinery

Adaptive capacity (A)

Net income of rural residents/Yuan(-)

$$
\begin{aligned}
& \text { Arable land per } \\
& \text { capita/hm2(-) }
\end{aligned}
$$

Income determines the drought disaster recovery capabilities

The performance of the population effect and the pressure of land

Manifest the level of mechanization of

Agricultural power agricultural production, in unit of arable land / but also reflect the size of $\left(\mathrm{w} / \mathrm{hm}^{2}\right)(-) \quad$ the irrigation mechanical power during drought period
Regional

Statistical Yearbook of Beijing

Statistical
Yearbook of

Statistical
Yearbook of

\section{Beijing \\ Regiona}




\subsubsection{The Processing of Indicator Data}

1) Difference value between evaporation and rainfall

Study area's main agricultural drought duration was the growth period of winter wheat from October to the second year of June. Firstly, reference crop evapotranspiration ET0 use Penman formula recommended by Food and Agriculture Organization of the United Nations. Calculating the difference value between evaporation and rainfall in 16 meteorological stations of the study area, secondly, use ArcGIS regression kriging spatial interpolation to deal with the data to get the 90meter $\times 90$ meter raster map of difference value between evaporation and rainfall in the whole study area. Thirdly, count the average value of the difference value between evaporation and rainfall in each evaluation unit.

2) Natural element indicators

The average elevation and average slope value in the evaluation unit were calculated by DEM image and slope map through ArcGIS. The drainage density values in evaluation unit was the intersection of the river vector layers and administrative boundaries vector layers in the study area by ArcGIS, then open the property sheet to sum its rivers' total length in each evaluation unit, latter, divided by the evaluation unit area.

\subsubsection{Indicators Quantify and Weight Calculations}

Analytic Hierarchy Process (AHP) is a method of evaluation and decision-making which is a combination of qualitative and quantitative analysis, quantitative analysis of the person's qualitative subjective judgment, making variety of heterogeneous data integration, it is a currently widely used to determine the weight. However, using AHP to build a judgment matrix will be a certain degree of subjectivity because the experts' judgment of the relative importance of the indicators varies different, while insufficient application of existing quantitative information is also an obvious inadequacy. Therefore, we can use the improved analytic hierarchy process method to calculate the weight of drought vulnerability indicators. Firstly, divide the evaluation behavior into three levels. Target layer is evaluation of vulnerabilities; criterion level is three drought vulnerability factors (exposure, sensitivity, adaptive capacity); lowest level is index layer which belonged to the upper evaluation indicators.

Assume that there are $n$ number indicators involved in the evaluation, $N=\{1,2, \ldots$, $\mathrm{n}\}$, $\mathrm{P}$ is an indicator of vulnerability standard evaluation set, according to study of this article, $\mathrm{P}$ have 5 elements, that is any indicator divided as the five clustering by the standard. The $\mathrm{X}_{\mathrm{ab}}$ is the maximum membership grade of an indicator, according to the principle of maximum membership grade; the indicator is belonging to $b$ clustering. The clustering level of $\mathrm{X}_{\mathrm{ab}}$ which is maximum membership grade of an indicator belonging worse, the indicator of vulnerability is worse, the greater it caused vulnerability impact on the criterion level.

When two indicators are at the same level in criteria layer, the vulnerability impact on criteria layer are of equal importance; when the index $i$ is at worse vulnerability clustering level when compared with index $j$, then consider that index $i$ cause greater vulnerability impact on the criterion level than the index $j$. So: 


\begin{abstract}
9 The degree of vulnerability of the index $i$ is four levels lower than the index $j$
7 The degree of vulnerability of the index $i$ is three levels lower than the index $j$

5 The degree of vulnerability of the index $i$ is two levels lower than the index $j$

3 The degree of vulnerability of the index $i$ is one level lower than the index $j$

$d_{i j}=\{1$ The degree of vulnerability of the index $i$ is the same as the index $j$

$(1 / 3)$ The degree of vulnerability of the index $j$ is one level lower than the index $i$

$(1 / 5)$ The degree of vulnerability of the index $j$ is two levels lower than index $i$

$(1 / 7)$ The degree of vulnerability of index $j$ is three levels lower than the index $i$

(1/9) The degree of vulnerability of index $j$ is four levels lower than the index $i$
\end{abstract}

Finally, use the K-means algorithm for the discretization of each index data indicators. The data is divided into five levels, making assignments for each indicator positive correlation with vulnerability assigned as 2,4,6,8,10; negatively correlated with vulnerability assigned as 10,8,6,4,2.

\title{
$3 \quad$ Results and Analysis
}

Making the weight of exposure, sensitivity and adaptive capacity in the criterion level equal. Using improved analytic hierarchy process to calculate the weight of the drought vulnerability indicators, and vulnerability evaluation results of all districts and counties in Beijing are shown in Table 2 and Table 3. View from the comprehensive weight of each indicator, Agricultural power in unit of arable land, the river network density, difference value between evaporation and rainfall, the three indicators have more important impact on target layer in drought vulnerability.

Table 2. Hierarchical structure and indicator weights of vulnerability evaluation

(Consistency has passed the examination)

\begin{tabular}{|c|c|c|c|c|c|}
\hline \multirow[b]{2}{*}{$\begin{array}{l}\text { Target } \\
\text { layer }\end{array}$} & \multicolumn{2}{|c|}{ Criterion level } & \multicolumn{2}{|l|}{ Index layer } & \multirow[b]{2}{*}{$\begin{array}{l}\text { Comprehensive } \\
\text { weight }\end{array}$} \\
\hline & Element & $\begin{array}{l}\text { Single- } \\
\text { layer } \\
\text { weight } \\
\end{array}$ & Element & $\begin{array}{l}\text { Single- } \\
\text { layer } \\
\text { weight }\end{array}$ & \\
\hline \multirow{7}{*}{$\begin{array}{c}\text { Drought } \\
\text { vulnerability }\end{array}$} & \multirow{4}{*}{$\begin{array}{l}\text { Exposure } \\
\text { (E) }\end{array}$} & \multirow{4}{*}{$1 / 3$} & $\begin{array}{c}\text { Difference value } \\
\text { between evaporation } \\
\text { and rainfall/mm }(+)\end{array}$ & 0.3534 & 0.1178 \\
\hline & & & Average elevation $/ \mathrm{m}(+)$ & 0.1176 & 0.0392 \\
\hline & & & $\begin{array}{c}\text { Average slope } /^{\circ} \\
(+)\end{array}$ & 0.1755 & 0.0585 \\
\hline & & & $\begin{array}{l}\text { The river network } \\
\text { density/ } \\
\left(\mathrm{km} / \mathrm{km}^{2}\right) \quad(-)\end{array}$ & 0.3534 & 0.1178 \\
\hline & \multirow{3}{*}{$\begin{array}{l}\text { Sensitivity } \\
\text { (S) }\end{array}$} & \multirow{3}{*}{$1 / 3$} & $\begin{array}{c}\text { Forest coverage } 1 \% \\
(-)\end{array}$ & 0.092 & 0.0307 \\
\hline & & & $\begin{array}{l}\text { The irrigation Index } \\
(-)\end{array}$ & 0.1495 & 0.0498 \\
\hline & & & $\begin{array}{l}\text { Winter wheat planting } \\
\text { ratio }(+)\end{array}$ & 0.1123 & 0.0374 \\
\hline
\end{tabular}


Table 2. (Continued.)

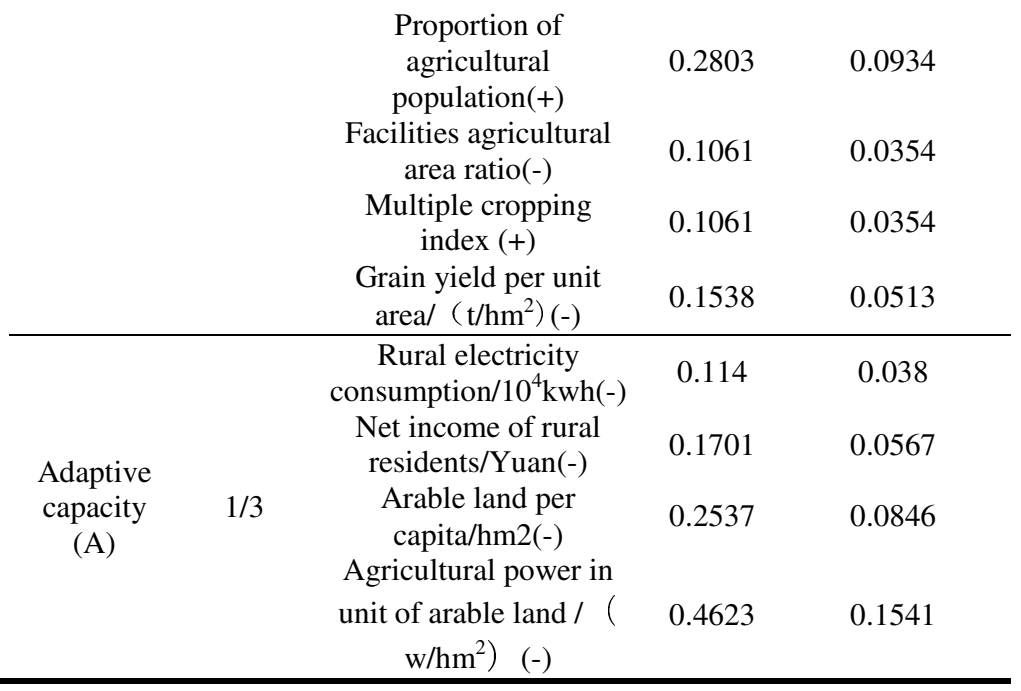

Table 3. Vulnerability assessment of districts and counties in Beijing (Exposure element index assessment result)

\begin{tabular}{cccccc}
\hline $\begin{array}{c}\text { Evaluation } \\
\text { index }\end{array}$ & $\begin{array}{c}\text { Difference value between } \\
\text { evaporation and rainfall }\end{array}$ & $\begin{array}{c}\text { Average } \\
\text { elevation }\end{array}$ & $\begin{array}{c}\text { Average } \\
\text { slope }\end{array}$ & $\begin{array}{c}\text { The river } \\
\text { network } \\
\text { density }\end{array}$ & $\begin{array}{c}\text { Element } \\
\text { index } \\
\text { result }\end{array}$ \\
\hline Daxing & 1.178 & 0.0784 & 0.117 & 0.4712 & $\mathbf{1 . 8 4 4 6}$ \\
Miyun & 0.7068 & 0.2352 & 0.585 & 0.9424 & $\mathbf{2 . 4 6 9 4}$ \\
Pinggu & 0.7068 & 0.0784 & 0.585 & 0.9424 & $\mathbf{2 . 3 1 2 6}$ \\
Yanqing & 0.2356 & 0.392 & 0.468 & 1.178 & $\mathbf{2 . 2 7 3 6}$ \\
Huairou & 0.7068 & 0.392 & 0.351 & 0.9424 & $\mathbf{2 . 3 9 2 2}$ \\
Tongzhou & 1.178 & 0.0784 & 0.351 & 0.7068 & $\mathbf{2 . 3 1 4 2}$ \\
Changping & 0.4712 & 0.1568 & 0.117 & 0.9424 & $\mathbf{1 . 6 8 7 4}$ \\
Shunyi & 0.7068 & 0.0784 & 0.468 & 0.9424 & $\mathbf{2 . 1 9 5 6}$ \\
Mengtougou & 0.2356 & 0.3136 & 0.234 & 0.4712 & $\mathbf{1 . 2 5 4 4}$ \\
Fengtai & 0.9424 & 0.0784 & 0.468 & 0.2356 & $\mathbf{1 . 7 2 4 4}$ \\
Fangshan & 0.2356 & 0.1568 & 0.234 & 0.9424 & $\mathbf{1 . 5 6 8 8}$ \\
\hline
\end{tabular}

(Sensitivity element index assessment result) 
Table 3. (Continued.)

\begin{tabular}{|c|c|c|c|c|c|c|c|c|}
\hline $\begin{array}{l}\text { Evaluation } \\
\text { index }\end{array}$ & $\begin{array}{c}\text { Forest } \\
\text { coverage }\end{array}$ & $\begin{array}{l}\text { The } \\
\text { irrigatio } \\
\text { n Index }\end{array}$ & $\begin{array}{c}\text { Winter } \\
\text { wheat } \\
\text { planting } \\
\text { ratio }\end{array}$ & $\begin{array}{c}\text { Proportion } \\
\text { of agricul } \\
\text { tural } \\
\text { population }\end{array}$ & $\begin{array}{c}\text { Facilities } \\
\text { agricultur } \\
\text { al area } \\
\text { ratio }\end{array}$ & $\begin{array}{c}\text { Multiple } \\
\text { cropping } \\
\text { index }\end{array}$ & $\begin{array}{l}\text { Grain } \\
\text { yield } \\
\text { per unit } \\
\text { area }\end{array}$ & $\begin{array}{c}\text { Element } \\
\text { index } \\
\text { result }\end{array}$ \\
\hline Daxing & 0.307 & 0.0996 & 0.0748 & 0.5604 & 0.1416 & 0.354 & 0.1026 & 51.64 \\
\hline Miyun & 0.0614 & 0.3984 & 0.2992 & 0.1868 & 0.354 & 0.2124 & 0.3078 & 1.82 \\
\hline Pinggu & 0.0614 & 0.0996 & 0.2244 & 0.5604 & 0.354 & 0.354 & 0.1026 & $5 \quad 1.7564$ \\
\hline Yanqing & 0.1228 & 0.2988 & 0.374 & 0.3736 & 0.354 & 0.1416 & 0.4104 & $+\quad \mathbf{2 . 0 7 5 2}$ \\
\hline Huairou & 0.1842 & 0.1992 & 0.374 & 0.3736 & 0.2832 & 0.2124 & 0.2052 & $2 \quad 1.8318$ \\
\hline Tongzhou & 0.307 & 0.0996 & 0.1496 & 0.7472 & 0.1416 & 0.2832 & 0.2052 & $2 \quad 1.9334$ \\
\hline Changping & 0.1842 & 0.1992 & 0.2244 & 0.3736 & 0.0708 & 0.0708 & 0.513 & 1.636 \\
\hline Shunyi & 0.307 & 0.0996 & 0.0748 & 0.934 & 0.1416 & 0.354 & 0.1026 & $5 \quad 2.0136$ \\
\hline $\begin{array}{c}\text { Mengtoug } \\
\text { ou }\end{array}$ & 0.2456 & 0.498 & 0.2992 & 0.1868 & 0.0708 & 0.354 & 0.513 & 2.1674 \\
\hline Fengtai & 0.2456 & 0.2988 & 0.1496 & 0.1868 & 0.0708 & 0.0708 & 0.513 & 1.5354 \\
\hline Fangshan & 0.2456 & 0.1992 & 0.2992 & 0.3736 & 0.2124 & 0.2124 & 0.3078 & 1.8502 \\
\hline & & (Ada & apact & InE III & $\mathrm{x}$ assessme & t result) & & \\
\hline $\begin{array}{l}\text { Evaluation } \\
\text { index }\end{array}$ & $\begin{array}{r}\mathrm{R} \\
\text { elec } \\
\text { consu } \\
\end{array}$ & $\begin{array}{l}\text { Iral } \\
\text { ricity } \\
\text { mption }\end{array}$ & $\begin{array}{l}\text { Net incon } \\
\text { rural resic }\end{array}$ & $\begin{array}{l}\text { ne of } \\
\text { dents }\end{array}$ & $\begin{array}{l}\text { Arable } \\
\text { and per } \\
\text { capita } \\
\end{array}$ & $\begin{array}{l}\text { Agricultur } \\
\text { power in un } \\
\text { of arable lat }\end{array}$ & & $\begin{array}{l}\text { Element } \\
\text { index } \\
\text { result } \\
\end{array}$ \\
\hline Daxing & & 152 & 0.340 & & 0.6768 & 0.9246 & & 2.0936 \\
\hline Miyun & & 38 & 0.567 & & 0.3384 & 1.2328 & & 2.5182 \\
\hline Pinggu & & 228 & 0.453 & & 0.6768 & 0.3082 & & 1.6666 \\
\hline Yanqing & & 38 & 0.567 & & 0.1692 & 1.541 & & 2.6572 \\
\hline Huairou & & 304 & 0.453 & & 0.6768 & 0.3082 & & 1.7426 \\
\hline Tongzhou & & 976 & 0.226 & & 0.6768 & 1.541 & & 2.5206 \\
\hline Changping & & 976 & 0.340 & & 0.846 & 1.541 & & 2.8032 \\
\hline Shunyi & & 152 & 0.113 & & 0.5076 & 0.9246 & & 1.6976 \\
\hline Mengtougou & & 38 & 0.226 & & 0.846 & 1.2328 & & 2.6856 \\
\hline Fengtai & & 976 & 0.113 & & 0.846 & 0.6164 & & 1.6518 \\
\hline Fangshan & & 152 & 0.340 & & 0.6768 & 0.6164 & & 1.7854 \\
\hline & & & (Vulnerab & ty assessn & ment result) & & & \\
\hline Name of dis & istrict & Daxing & Miyun & Pinggu & Yanqi & Huai & rou & Tongzhou \\
\hline $\begin{array}{r}\text { Vulnerabil } \\
\text { assessment } \mathrm{r}\end{array}$ & $\begin{array}{l}\text { ility } \\
\text { result }\end{array}$ & 5.5782 & 6.8076 & 5.7356 & 5 & 66 & & 6.7682 \\
\hline Name of dis & istrict & Changping & Shunyi & Mengtoug & Fengt & Fang & shan & \\
\hline $\begin{array}{r}\text { Vulnerabil } \\
\text { assessment } \mathrm{r}\end{array}$ & $\begin{array}{l}\text { ility } \\
\text { result }\end{array}$ & 6.1266 & 5.9068 & 6.1074 & 4.9 & 16 & 14 & \\
\hline
\end{tabular}




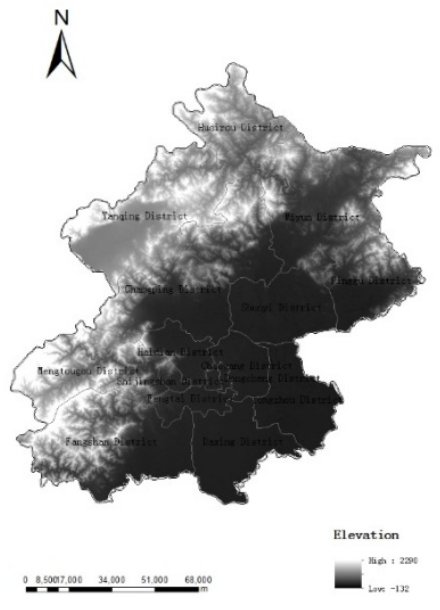

Fig. 1. Topography and administrative divisions of Beijing

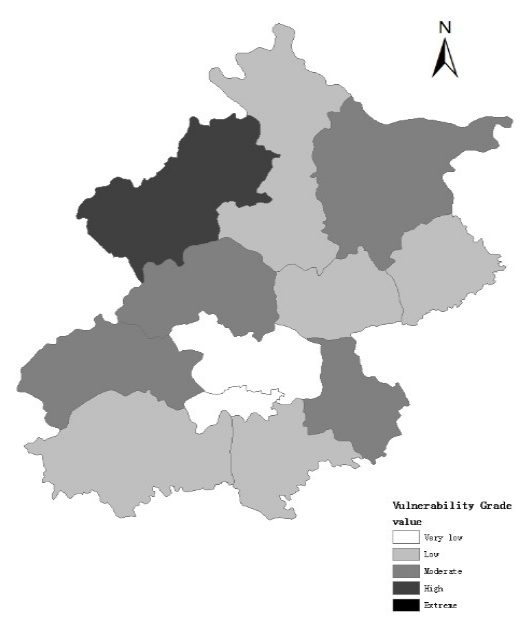

Fig. 2. The distribution of vulnerability grade

Beijing's topography and administrative divisions are shown in Figure 1. The level of vulnerability distribution is shown in Figure 2.

\section{Conclusions}

In this study, use the drought vulnerability assessment which considers three main factors. First, VAM is an effective method for analyze vulnerability of the various elements, VAM assessment methods is better at determining the impact factors of drought vulnerability, in order to analyze the area which may frequently occur drought. Prevent or reduce disaster losses before the drought had occurred.

However, using AHP to build a judgment matrix will be a certain degree of subjectivity because the experts' judgment of the relative importance of the indicators varies different, while insufficient application of existing quantitative information is also an obvious inadequacy. When using the improved analytic hierarchy process method to calculate the weight of drought vulnerability indicators, can avoid judgment matrix randomness which varies from person to person. This method is more objectivity, very stability, simple and easy to calculate. Using K-means algorithm to making index data discretization, can avoid the disadvantages of equalwidth interval method which is too simple and easily influenced by the amount of data. Index data discretization has directly impact on the assignment of the index data and the accuracy of the final vulnerability assessment. Therefore, a suitable discretization method is particularly important.

Look at the result of index system for drought vulnerability assessment, the exposure index of Miyun, Pinggu, Huairou, Tongzhou are higher, indicating that the four districts experienced larger degree of drought stress. The sensitivity index of 
Mentougou, Shunyi, Yanqing are higher, suggesting that in the three districts, the extent of agricultural system elements susceptible to the effects of drought are larger. Adaptive capacity index of Changping, Yanqing, Mentougou, Miyun are higher, showing that when these four districts occurred drought, the capability of stakeholders in the agricultural system taking measures to reduce the effects of drought in the predisaster and after disaster are poor. Integrate the three elements, the greater drought vulnerability districts are Yanqing, Miyun, Tongzhou, Mentougou and Changping.

\section{References}

1. Blaikie, P.M.: At risk: natural hazards, people's vulnerability, and disasters. Psychology Press (1994)

2. Keyantash, J., Dracup, J.A.: The quantification of drought: an evaluation of drought indices. Bulletin of the American Meteorological Society 83(8), 1167-1180 (2002)

3. Wilhelmi, O.V., Wilhite, D.A.: Assessing vulnerability to agricultural drought: A Nebraska case study. Natural Hazards 25(1), 37-58 (2002)

4. Liu, L., Liu, S., Liu, P., et al.: Synthetic analysis and quantitative estimation of the agricultural vulnerability to drought disaster in Hunan Province. Journal of Natural Disasters 11(4), 78-83 (2002) (in Chinese with English abstract)

5. Wang, X., Qiao, Y., Shen, R.: Drought risk assessment model for irrigation region. Advances in Water Science (1), 121-130 (2003) (in Chinese with English abstract)

6. Ni, S., Gu, Y., Wang, H.: Study on frangibility zoning of agricultural drought in China. Advances in Water Science (5), 705-709 (2005) (in Chinese with English abstract)

7. Wang, J., Shang, Y., Su, Y., et al.: A vulnerability diagnosis of agricultural drought disasters and regional sustainable development in China. Journal of Beijing Normal University: Social Science Edition (3), 130-137 (2005) (in Chinese with English abstract)

8. Qiu, L., Wang, W., Chen, S.: Quantitative estimation for vulnerability of agricultural drought disaster using variable fuzzy analysis method. Transactions of the CSAE 27(suppl. 2), 61-65 (2011) (in Chinese with English abstract)

9. Chen, P., Chen, X.: Evaluating drought vulnerability of agricultural system in Poyang Lake Ecological Economic Zone, China. Transactions of the CSAE 27(8), 8-13 (2011) (in Chinese with English abstract)

10. Simelton, E., Fraser, E.D.G., Termansen, M., et al.: Typologies of crop-drought vulnerability: an empirical analysis of the socio-economic factors that influence the sensitivity and resilience to drought of three major food crops in China (1961-2001). Environmental Science \& Policy 12(4), 438-452 (2009)

11. Quiring, S.M., Papakryiakou, T.N.: An evaluation of agricultural drought indices for the Canadian prairies. Agricultural and Forest Meteorology 118(1-2), 49-62 (2003)

12. Yin, Z., Huang, W., Chen, J.: Dynamic evaluation of agricultural drought based on soil moisture simulation. Journal of Irrigation and Drainage 3, 5-8 (2009) (in Chinese with English abstract)

13. Wang, S., Huo, Z., Li, S., et al.: Water deficiency and climatic productive potentialities of winter wheat in north of China: study on its dynamic change in recent 40 years. Journal of Natural Disasters 1, 121-130 (2003) (in Chinese with English abstract)

14. Sun, N., Feng, L.: Assessing the climatic risk to crop yield of winter wheat using crop growth models. Transactions of the CSAE 21(2), 106-110 (2005) (in Chinese with English abstract) 
15. Zhang, W., Zhao, C., Kang, X.: Study on methodology for risk assessment and division of winter wheat drought hazard in Hebei province. Agricultural Research in the Arid Areas 2, 10-16 (2009) (in Chinese with English abstract)

16. Wang, S.: Risk assessment and regionalization study on winter wheat drought in north of china. China Agricultural University (2004)

17. Zhang, C.: Study of the evaluate and zone methods on winter wheat drought risk based on GIS in Jing-Jin-JI region. Hebei Normal University (2010)

18. Fontaine, M.M., Steinemann, A.C.: Assessing vulnerability to natural hazards: impactbased method and application to drought in Washington State. Natural Hazards Review 10(1), 11-18 (2009) 